\section{ПАМЯТИ АКАДЕМИКА} Н. П. ЛАВЕРОВА

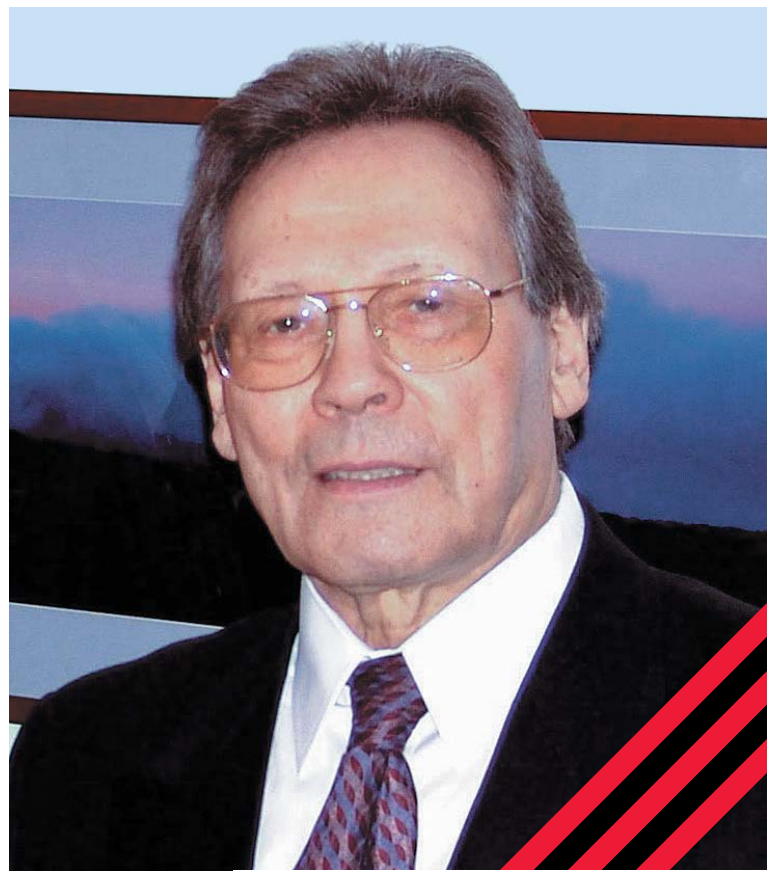

27 ноября 2016 г. после продолжительной и тяжелой болезни на 87-м году ушел из жизни признанный лидер отечественных ученых в области геологии, геохимии урана, радиоэкологии, развития сырьевой базы ТЭК, талантливый организатор науки и видный общественный деятель, председатель Национального комитета геологов России, Межведомственной комиссии Совета безопасности Российской Федерации по экологической безопасности, Научного совета РАН по проблемам экологии и чрезвычайным ситуациям, Координационного совета РАН по наукам о Земле, Межведомственной комиссии по проблеме «Экологическая стойкость и сертификация техники и материалов», Межведомственного научно-технического совета по проблемам радиологической безопасности, научный руководитель Института геологии рудных месторождений, петрографии, минералогии и геохимии РАН, академик Николай Павлович Лаверов.

Это достаточно короткий перечень государственных и научных должностей, которые занимал Н. П. Лаверов, но он был еще и председателем редакционного совета нашего журнала.

Николай Павлович получил признание в области геологии, геохимии урана, разведки и освоения полезных ископаемых. Трудно переоценить его огромный вклад в создание мощной минеральносырьевой базы в нашей стране. Его заслугой стали пионерские исследования по геологии российской Арктики, а также геоэкологии и изучению Земли из космоса. Надо отдать должное таланту академика
Н. П. Лаверова - он предвидел большой интерес к Арктике не только в нашей стране, но и во всем мире, понимал масштаб и глубину решения арктических проблем. Для экономического и социального развития арктического региона в целях обеспечения стратегических интересов страны Н. П. Лаверов всегда подчеркивал необходимость его глубокого изучения и развертывания научных исследований в таких областях, как геофизика, геология, география, гидрометеорология, сейсмология, океанология, биология, экология.

Академик Н. П. Лаверов последовательно отстаивал приоритет экологической безопасности при организации крупномасштабных современных производств, особенно в Арктике. Большое значение он придавал «Стратегическому Мастер-плану утилизации и экологической реабилитации выведенных из эксплуатации объектов атомного флота и обеспечивающей инфраструктуры в северо-западном регионе России», разработанному по заказу «Росатома» и при научном руководстве ИБРАЭ РАН в 2005-2007 гг.

По инициативе Н. П. Лаверова в Президиуме РАН с 2014 г. сформирована и продолжает осуществляться программа «Поисковые фундаментальные научные исследования в интересах развития Арктической зоны Российской Федерации».

В 2010 г. Институт проблем безопасного развития атомной энергетики РАН обратился к Николаю Павловичу с инициативой издания научного и информационно-аналитического журнала «Арктика: 
экология и экономика». Он поддержал идею создания академического научного журнала, освещающего состояние Арктики на фоне повышенного мирового внимания в первую очередь к ее богатым природным ресурсам, расширению научно-исследовательской деятельности, включая мониторинг климатического и экологического влияния Арктики на всю планету, и к социально-экономическому развитию этого региона. Идею издания журнала поддержали и видные ученые Российской академии наук, а также ученые и специалисты отраслевых научных учреждений, ведомств и руководители региональных структур. ИБРАЭ РАН выступил в качестве учредителя журнала, а Н. П. Лаверов согласился возглавить его редакционный совет. Для того чтобы журнал был интересен широкой читательской аудитории и полезен представленной в нем современной научной и научно-технической информацией, Николай Павлович пригласил в состав редакционного совета известных ученых, специалистов в различных областях знаний, столь полезных и необходимых для изучения и освоения Арктики. Они откликнулись на его обращение.

11 марта 2011 г. в Президиуме Российской академии наук под председательством академика Н. П. Лаверова состоялось совместное заседание редакционного совета и редакционной коллегии журнала, на котором были рассмотрены вопросы обеспечения высокого научного уровня издания, подготовки актуальных статей, обобщающих научные и практические достижения в комплексном решении проблем Арктической зоны Российской Федерации и формирования широкой читательской аудитории. В ходе заседания были обсуждены направления, которые должны освещаться в журнале, и сформированы его рубрики. Вскоре после совместного заседания вышел первый номер журнала.

Члены редакционного совета и редакционной коллегии журнала принимают активное участие в подготовке и рецензировании статей, а также привлекают к этой работе специалистов и ученых подведомственных организаций. За прошедшее время сформировалось крепкое ядро авторитетного авторского коллектива, которое все больше расширяется за счет притока новых людей как из арктических, так и из неарктических регионов страны, неравнодушных к проблемам социально-экономического развития Арктической зоны Российской Федерации. Интерес к публикуемым в журнале материалам постоянно возрастает, с 2015 г. он включен в Перечень ВАК, также это можно заметить по возрастающему с каждым годом рейтингу журнала в Российском индексе научного цитирования.

Журнал восполнил очевидный пробел в научной периодике, который стал особенно ощутимым на фоне прогрессивно возрастающей роли Арктики. Он стал практически единственным в стране специализированным научным периодическим изданием, ориентированным на комплексное освещение актуальных проблем изучения и экономического освоения Арктики. И сегодня он продолжает оставаться таковым, хотя за это время появились и другие электронные и печатные издания по арктическим проблемам более узкой направленности

При беседах с Николаем Павловичем относительно дальнейшего развития журнала его советы всегда были конструктивны и полезны. Надо отметить, что, имея богатый опыт руководства научными изданиями (а он был главным редактором нескольких журналов), Николай Павлович особое внимание обращал на подбор актуальных, востребованных современностью материалов, а также на кропотливую и бережную работу с авторами, в частности на то, чтобы сохранялся уникальный авторский стиль.

Коллектив редакции всегда будет гордиться тем, что довелось работать с таким необыкновенным человеком, как академик Н. П. Лаверов. Жизненный путь Николая Павловича Лаверова - замечательный пример беззаветного служения Родине и преданности науке.

Светлая память о Николае Павловиче навсегда сохранится в наших сердцах! 